\title{
KOMPOSISI DAN KELIMPAHAN PLANKTON DI WADUK CIRATA
}

(Trophic status of Cirata Reservoir noise in terms of plankton abundance)

\author{
${ }^{\otimes}$ Pigoselpi Anas, Iis Jubaedah, Lilis Supenti, Dinno Sudinno \\ Sekolah Tinggi Perikanan, Jurusan Penyuluhan Perikanan \\ Jalan Cikaret Nomor 2 Bogor 16001, Jawa Barat
}

Diterima: 10 Agustus 2017 ; Disetujui: 27 Agustus 2017

\begin{abstract}
ABSTRAK
Penelitian tentang "Komposisi Dan Kelimpahan Plankton Di Waduk Cirata " telah dilaksanakan pada bulan agustus 2017. tujuan dari penelitian ini untuk mengetahui komposisi dan kelimpahan plankton di waduk Cirata. Sampel diambil dari 3 stasiun pengamatan dan pada setiap stasiun pengamatan pengambilan sampel dilakukan pada tiga kedalaman. Titik pengambilan sampel ditentukan dengan metode purposive sampling. Sampel diambil dengan menggunakan plankton net. Identifikasi sampel dilakukan di Laboratorium, Hasil penelitian didapatkan Genera fitoplankton yang ditemukan di Waduk Cirata sebanyak 19-26 genera yang mewakili 4-5 kelas, yaitu Chlorophyceae, Cyanophyceae, Bacillariophyceae, Dinophyceae dan Euglenaphyceae. Genera zooplankton yang ditemukan di Waduk Cirata sebanyak 12-13 genera yang mewakili kelas, yaitu Rotifera, Rhizopoda, Ciliata dan Malacostraca. Kelimpahan fitoplankton berkisar $91.200-1,328.180 \mathrm{Sel} / \mathrm{m}^{3}$ dan kelimpahan Zooplankton berkisar 19.500 - 426.020 Sel/m³,
\end{abstract}

Kata kunci: kelimpahan plankton, waduk cirata

\begin{abstract}
ABSTRAC
Research on "Composition And Abundance of Plankton In Cirata Reservoir" was carried out in August 2017. The purpose of this research is to know the composition and abundance of plankton in Cirata reservoir. Samples were taken from 3 observation stations and at each observation station the samples were taken at three depths. The sampling point is determined by purposive sampling method. Samples were taken using plankton net. Identification of the sample was done in the laboratory. The results of Genera phytoplankton found in Cirata Reservoir were 19-26 genera representing 4-5 classes, namely Chlorophyceae, Cyanophyceae, Bacillariophyceae, Dinophyceae and Euglenaphyceae. Genera zooplankton found in Reservoir Cirata as many as 12-13 genera that represent classes, namely Rotifera, Rhizopoda, Ciliata and Malacostraca. The abundance of phytoplankton ranged from 91,200 - 1,328,180 cells / $\mathrm{m} 3$ and the abundance of Zooplankton ranged from 19,500 - 426,020 Cells / m3.
\end{abstract}

Keywords: plankton abundance, cirata reservoir.

\section{PENDAHULUAN}

Waduk Cirata berada di tengahtengah Daerah Aliran Sungai Citarum, Waduk ini di kelola oleh 3 Kabupaten

$\triangle$ Penulis Korespondensi : Alamat Surel : pigoselpianas@yahoo.com yaitu Kabupaten Cianjur, Kabupaten Bandung dan Kabupaten Purwakarta. Waduk Cirata merupakan waduk yang dalam, dengan kedalaman rata-rata sekitar 34,9 m (Prihadi 2004). Sejak menjadi genangan permanen, Waduk Cirata 
berkarakteristik perairan umum. Karena itu, Cirata memiliki berbagai potensi di bidang sosial ekonomi, seperti sumber pengairan sawah, air bersih, air minum, tempat budidaya ikan, wahana rekreasi, dan sarana perhubungan.. Dari berbagai tujuan dan pemanfaatan tersebut dapat memberikan beban masukan tersendiri bagi perairan waduk. Beban masukan tersebut, akan menjadi sumber penambahan unsur hara perairan yang juga dapat menyebabkan terjadinya berbagai masalah perairan, seperti proses eutrofikasi yang terjadi ketika beban masukan tersebut berlebihan sehingga menyebabkan turunnya kualitas air, sehingga akan mengganggu pula kehidupan fitoplankton sebagai produsen primer perairan

Plankton adalah organisme baik tumbuhan maupun hewan yang umumnya berukuran relatif kecil (mikro), hidup melayang-layang di air, tidak mempunyai daya gerak/kalaupun ada daya gerak relatif lemah sehingga distribusinya sangat dipengaruhi oleh daya gerak air, sepeti arus dan lainnya (Nybakken, 1992). Oleh karena itu perubahan yang terjadi dalam perairan sebagai akibat dari adanya beban masukan yang ada akan menyebabkan perubahan pada komposisi, kelimpahan dan distribusi dari komunitas plankton. Maka dari itu keberadaan plankton dapat dijadikan sebagai indikator kondisi kualitas perairan, selain itu plankton dapat digunakan sebagai indikator perairan karena sifat hidupnya yang relatif menetap, jangka hidup yang relatif panjang dan mempunyai toleransi spesifik pada lingkungan.. Dengan demikian keberadaan plankton sendiri bisa dijadikan sebagai indikator perairan

\section{TUJUAN}

Adapun tujuan dari penelitian ini untuk mengetahui jenis-jenis ,kelimpahan dan keanekaragaman plankton di waduk Cirata

\section{METODE PENELITIAN}

Penelitian ini dilakukan pada bulan agustus 2017. stasiun penelitian dibagi menjadi tiga stasiun yang mewakili

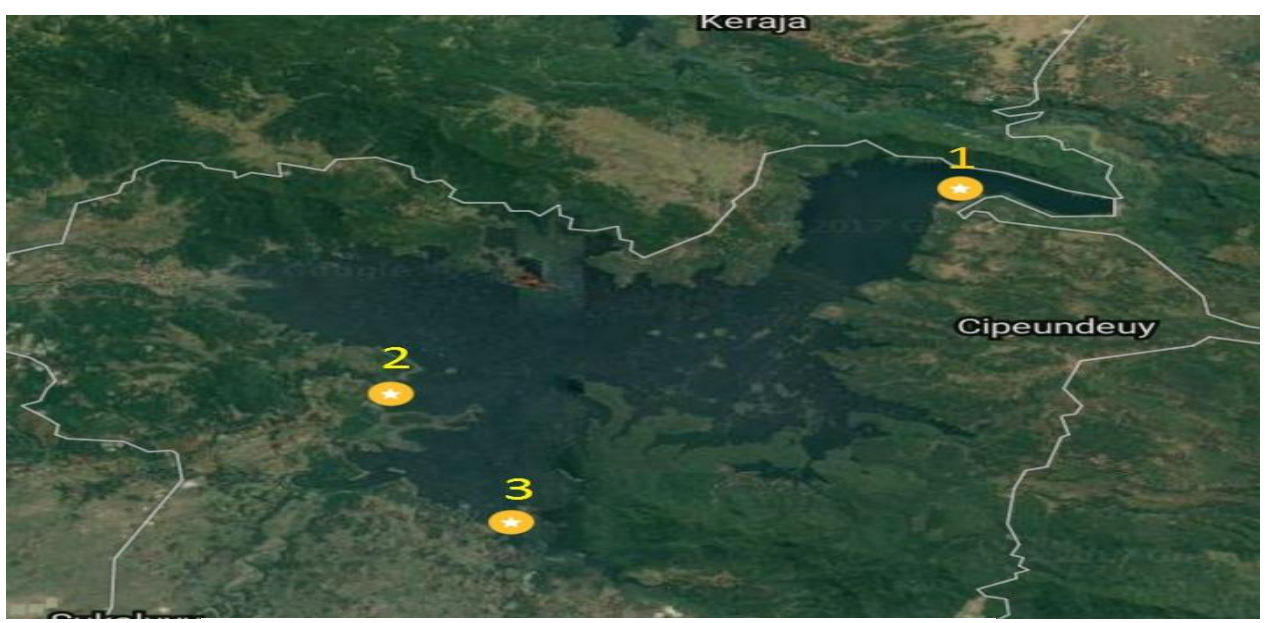

Gambar 1. Lokasi Penelitian 
perairan Waduk Cirata, Jawa Barat (Gambar 1).

Sampel air diambil dengan menggunakan kemmerer water sampler secara vertikal berdasarkan kedalaman perairan $(0,15$, dan 30 meter) Kemudian sampel air disaring dengan menggunakan plankton net No. 25 dengan ukuran mata jaring 60 $\mu \mathrm{m}$ dan diawetkan dengan larutan lugol sebanyak 5 tetes. Analisis sampel plankton dilakukan di laboratorium plankton dengan menggunakan buku identifikasi untuk plankton air tawar Kelimpahan plankton dihitung dengan metode Pencacahan (Sensus- SRC). Beberapa indeks biologi fitoplankton yang dianalisis adalah indeks keanekaragaman Shannon, indeks keseragaman atau Evenness (e), dan indeks dominansi.

\section{HASIL DAN PEMBAHASAN}

\section{A. Kondisi Perairan Waduk Cirata}

Amonia

Amonia $\left(\mathrm{NH}_{3}\right)$ dan garamgaramnya bersifat mudah larut dalam air. Ion amonium adalah bentuk transisi dari amonia. Amonia banyak digunakan dalam proses produksi urea, industry bahan kimia (asam nitrat, amonium, fosfat, amonium nitrat, dan amonium sulfat ), serta industri bubur kertas dan kertas (pulp dan paper). Sumber amonia di perairan adalah pemecahan nitrogen organik (protein dan urea) dan nitrogen anorganik yang terdapat di dalam tanah dan air, yang berasal dari dekomposisi bahan organik (tumbuhan dan biota akuatik yang telah mati) oleh mikroba dan jamur. proses ini dikenal dengan istilah amonifikasi. Reduksi nitrat (denitrifikasi) oleh aktivitas mikroba pada kondisi anaerob, yang merupakan proses yang biasa terjadi pada pengolahan limbah, juga menghasilkan gas amonia dan gas-gas lainnya, misalnya $\mathrm{N}_{2} \mathrm{O}, \mathrm{NO}_{2}, \mathrm{NO}$, dan $\mathrm{N}_{2}$ ( Novotny dan Olem, 1994 dalam Effendi 2003). Nilai kandungan Amonia Perairan Cirata yang terukur sewaktu penelitian berkisar 0,204 - 0,422 mg/l. Kadar amonia pada perairan alami biasanya kurang dari 0,1 mg/liter (McNeely et al.,1979 dalam Effendi, 2003 ). Kadar amonia bebas yang tidak terionisasi (NH3) pada perairan tawar sebaliknya tidak lebih dari 0,02 mg/liter. Jika kadar amonia bebas lebih dari $0,02 \mathrm{mg} / \mathrm{liter}$, perairan bersifat toksik bagi beberapa jenis ikan (Sawyer dan McCarty, 1978 dalam Effendi,2003).Kadar amonia yang tinggi dapat merupakan indikasi adanya pencemaran bahan organik yang berasal dari limbah domestik, industri, dan limpasan (run-off) pupuk pertanian. kadar amonia yang tinggi juga dapat ditemukan pada dasar danau atau waduk yang mengalami kondisi tanpa oksigen (anoxic).

Nitrat

Nitrat $\left(\mathrm{NO}_{3}\right)$ adalah bentuk utama nitrogen di perairan alami dan merupakan 
nutrient utama bagi pertumbuhan tanaman dan algae. Nitrat nitrogen sangat mudah larut dalam air dan bersifat stabil. senyawa ini dihasilkan dari proses oksidasi sempurna senyawa nitrogen di perairan. Nilai rata-rata kandungan nitrat Perairan Waduk Cirata yang terukur sewaktu penelitian berkisar < 0,001-1,088 mg/l. Menurut Leentvaar (1980) dalam subarijanti (1990), perairan dengan kandungan nitrat sebesar $<0,1 \quad \mathrm{ppm}$ termasuk perairan yang oligotropik, kandungan nitrat $0-0,15$ ppm termasuk perairan mesotropik dan kandungan nitrat $>0,2 \mathrm{ppm}$ adalah perairan eutropik

Fosfat

Fosfat merupakan bentuk fosfor yang dapat dimanfaatkan oleh tumbuhan (Dugan, 1972 dalam Effendi,2003) Kadar fosfor pada perairan alami berkisar antara 0,005 - 0,02 mg/liter $\mathrm{P}_{-} \mathrm{PO}_{4}$. Fosfat yang terukur di Perairan Waduk Cirata sewaktu penelitian berkisar $0,165-0,500 \mathrm{mg} / \mathrm{l}$. Klasifikasi fosfat di perairan yaitu 0.00 $0.02 \mathrm{mg} / \mathrm{l}$ adalah perairan dengan kesuburan rendah, konsentrasi berkisar $0.02-0.05 \mathrm{mg} / \mathrm{l}$ kesuburan sedang, dan konsentrasi $0.05-0.20 \mathrm{mg} / \mathrm{l}$ kesuburan perairan tinggi dan lebih dari $0.20 \mathrm{mg} / \mathrm{l}$ kesuburan sangat tinggi (Poernomo \& Hanafi 1982). Keberadaan fosfor secara berlebihan yang disertai dengan keberadaan nitrogen dapat menstimulir ledakan pertumbuhan algae di perairan (algae bloom). Algae yang berlimpah ini dapat membentuk lapisan pada permukaan air, yang selanjutnya dapat menghambat penetrasi oksigen dan cahaya matahari sehingga kurang menguntungkan bagi ekosistem perairan. Sedangkan berdasarkan kadar fosfor total, perairan diklasifikasikan menjadi tiga, (Yoshimura dalam Liaw, 1969 dalam Effendi, 2003), yaitu :

- Perairan dengan tingkat kesuburan rendah, memiliki kadar fosfat total berkisar antara $0-0,02 \mathrm{mg} / \mathrm{liter}$.

- Perairan dengan tingkat kesuburan sedang, memiliki kadar fosfat total berkisar antara 0,02-0,05 mg/liter.

- Perairan dengan tingkat kesuburan tinggi, memiliki kadar fosfat total 0,051 $-0,1 \mathrm{mg} / \mathrm{liter}$

Menurut Wetzel (1975) dalam Effendi (2003), perairan yang mempunyai kadar fosfat antara 0,031 - 0,1 digolongkan dalam perairan eutrofik

BOD

Biochemical Oxygen Demand atau kebutuhan oksigen biologis adalah jumlah oksigen yang dibutuhkan oleh mikroorganisme aerobik di dalam air lingkungan untuk memecah (mendegradasi) bahan buangan organik yang ada di dalam air lingkungan tersebut. Nilai BOD5 pada tiga stasiun penelitian 
berkisar antara 2,0 - 3,2 mg/l, Menurut Brower, et al, (1990), nilai konsentrasi BOD menunjukkan suatu kualitas perairan yang masih tergolong baik dimana apabila konsumsi $\mathrm{O} 2$ selama periode 5 hari berkisar sampai $5 \mathrm{mg} / \mathrm{l} \mathrm{O} 2$ maka perairan tersebut tergolong baik dan apabila konsumsi $\mathrm{O} 2$ berkisar antara $10 \mathrm{mg} / \mathrm{l}-20$ $\mathrm{mg} / \mathrm{l} \quad \mathrm{O} 2$ akan menunjukkan tingkat pencemaran oleh materi organik yang tinggi dan untuk air limbah nilai BOD umumnya lebih besar dari $100 \mathrm{mg} / \mathrm{l}$.

\section{B. Komposisi Jenis plankton di Perairan}

1..Jenis - jenis fitoplankton yang

ditemukan pada waduk Cirata

Tabel 1. Kelimpahan Fitoplankton $\left(\mathrm{sel} / \mathrm{m}^{3}\right)$ stasiun 1

\begin{tabular}{|l|l|l|l|}
\hline \multicolumn{1}{|c|}{ Organisme } & Permukaan & Tengah & Dasar \\
& & & \\
\hline BACILLARIOPHYCEAE & & & \\
Navicula sp. & 35.700 & 25.060 & 65.156 \\
Nitzschia sp. & 52.800 & 130.312 & 155.372 \\
Synedra sp. & 21.300 & 45.108 & 120.288 \\
Tabellaria sp. & 9.900 & 0 & 0 \\
Diatoma sp. & 6.300 & 0 & 10.024 \\
Eunotia sp. & 600 & 5.012 & 0 \\
Fragilaria sp. & 8.700 & 60.144 & 80.192 \\
Coscinodiscus sp. & 600 & 0 & 0 \\
Melosira sp. & 900 & 10.024 & 35.084 \\
Surirella sp. & 600 & 0 & 0 \\
Frustulia sp. & 1.800 & 0 & 0 \\
Cocconeis sp. & 300 & 0 & 0 \\
Bacillaria sp. & 0 & 0 & 15.036 \\
CHLOROPHYCEAE & & & \\
Ankistrodesmus sp. & 300 & 0 & 0 \\
Pediastrum sp. & 0 & 0 & 30.072 \\
Scenedesmus sp. & 600 & 10.024 & 5.012 \\
Spirogyra sp. & 7.200 & 0 & 0 \\
Microspora sp. & 0 & 20.048 & 0 \\
Genicularia sp. & 0 & 20.048 & 0 \\
Gonatozygon sp. & 9.300 & 20.048 & 15.036 \\
Docidium sp. & 0 & 5.012 & 0 \\
Crucigenia sp. & 2.400 & 20.048 & 0 \\
CYANOPHYCEAE & 0.300 & 0 & 0 \\
Oscillatoria sp. & & 0 & 15.036 \\
Anabaena sp. & & & \\
Phormidium sp. & & & \\
DINOPHYCEAE & & 0.384 \\
Peridinium sp. & & 060 & \\
\hline
\end{tabular}




\begin{tabular}{|l|l|l|l|}
\hline Jumlah Taksa & 20 & 13 & 12 \\
Kelimpahan $\left(\mathrm{Sel} / \mathrm{m}^{3}\right)$ & 183.600 & 395.948 & 706.692 \\
Indeks Keragaman & 2,232 & 2,150 & 2,062 \\
Indeks Keseragaman & 0,745 & 0,838 & 0,830 \\
Indeks Dominansi & 0,153 & 0,164 & 0,156 \\
\hline
\end{tabular}

Genera fitoplankton yang ditemukan di stasiun 1 Waduk Cirata selama penelitian sebanyak 26 genera yang mewakili 4 kelas, yaitu Chlorophyceae, Cyanophyceae, Bacillariophyceae, dan Dinophyceae yang tersebar di seluruh kedalaman. Genera fitoplankton dari kelas Bacillariophyceae merupakan genera yang paling banyak ditemukan. Jumlah masing-masing genera perkelas secara berturut-turut adalah 13 genera Bacillariophyceae, 9 genera Chlorophyceae, 3 genera Cyanophyceae, dan 1 genera Dinophyceae. Kelimpahan fitoplankton berkisar 183.600 - 706.692 $\mathrm{Sel} / \mathrm{m}^{3}$.

Dari Tabel 1 dapat dilihat bahwa indeks keanekaragaman fitoplankton berkisar antara 1,04-2,20. Hal ini menunjukkan bahwa stasiun1 memiliki tingkat keanekaragaman rendah. indeks keseragaman berkisar $0,745-0,838$ hal ini menunjukkan keseragaman tinggi, artinya penyebaran individu tersebut mendekati merata atau tidak ada spesies yang mendominasi. Nilai indeks dominansi berkisar 0,153-0,164. Hal ini disebutkan oleh Basmi (2000) bahwa kisaran nilai indeks dominansi mulai dari 0-1, apabila nilai yang didapatkan mendekati nol berarti di dalam struktur komunitas biota yang diamati tidak terdapat genus yang secara ekstrim mendominasi genus lainnya.

Tabel 2. Kelimpahan Fitoplankton $\left(\mathrm{sel} / \mathrm{m}^{3}\right)$ stasiun 2

\begin{tabular}{|l|l|l|l|}
\hline Organisme & Permukaan & Tengah & Dasar \\
\hline $\begin{array}{l}\text { BACILLARIOPHYCEAE } \\
\text { Navicula sp. }\end{array}$ & 600 & 15.036 & 10.024 \\
Nitzschia sp. & 3.300 & 105.252 & 90.216 \\
Synedra sp. & 900 & 20.048 & 25.060 \\
Pleurosigma sp. & 0 & 0 & 5.012 \\
Diatoma sp. & 13.200 & 70.168 & 60.144 \\
Fragilaria sp. & 600 & 0 & 0 \\
Coscinodiscus sp. & 0 & 10.024 & 0 \\
CHLOROPHYCEAE & & & \\
Ankistrodesmus sp. & 0 & 10.024 & 0 \\
\hline
\end{tabular}




\begin{tabular}{|l|l|l|l|}
\hline Scenedesmus sp. & 0 & 10.024 & 25.060 \\
Micrasterias sp. & 0 & 0 & 5.012 \\
Microspora sp. & 9.900 & 240.576 & 140.336 \\
Closterium sp. & 300 & 0 & 0 \\
\hline Staurastrum sp. & 0 & 5.012 & 5.012 \\
CYANOPHYCEAE & & & \\
Oscillatoria sp. & 37.200 & 310.744 & 932.232 \\
Aphanizomenon sp. & 19.200 & 0 & 20.048 \\
Spirulina sp. & 3.600 & 0 & 0 \\
DINOPHYCEAE & & & \\
Ceratium sp. & 0 & 20.048 & 10.024 \\
Peridinium sp. & 0 & 5.012 & 0 \\
EUGLENOPHYCEAE & & & \\
Euglena sp. & 2.400 & 10.024 & 0 \\
\hline Jumlah Taksa & 11 & 13 & 12 \\
Kelimpahan (Sel/m $\left.{ }^{3}\right)$ & 91.200 & 831.992 & 1.328 .180 \\
Indeks Keragaman & 1,689 & 1,723 & 1,159 \\
Indeks Keseragaman & 0,704 & 0,672 & 0,466 \\
Indeks Dominansi & 0,247 & 0,248 & 0,512 \\
\hline
\end{tabular}

Dari Tabel 2 dapat dilihat bahwa indeks Genera fitoplankton yang keanekaragaman fitoplankton berkisar ditemukan di stasiun 2 Waduk Cirata antara 1,159-1,723. Hal ini menunjukkan selama penelitian sebanyak 19 genera yang mewakili 5 kelas, yaitu Chlorophyceae, Cyanophyceae,Bacillariophyceae,Dinophy ceae dan Euglenaphyceae yang tersebar di seluruh kedalaman. Genera fitoplankton dari kelas Bacillariophyceae merupakan genera yang paling banyak ditemukan. Jumlah masing-masing genera perkelas secara berturut-turut adalah 7 genera Bacillariophyceae, 6 genera bahwa stasiun 2 memiliki tingkat keanekaragaman rendah. indeks keseragaman berkisar 0,466 - 0,704 hal ini menunjukkan keseragaman tinggi, artinya penyebaran individu tersebut mendekati merata atau tidak ada spesies yang mendominasi. Nilai indeks dominansi berkisar 0,247 - 0,512 Artinya tidak terdapat genus yang secara ekstrim mendominasi genus lainnya.

Chlorophyceae, 3 genera Cyanophyceae, 2 genera Dinophyceae dan 1 genera Euglenophyceae. Kelimpahan fitoplankton berkisar $91.200-1,328.180 \mathrm{Sel} / \mathrm{m}^{3}$. 
Tabel 3. Kelimpahan Fitoplankton $\left(\mathrm{sel} / \mathrm{m}^{3}\right)$ stasiun 3

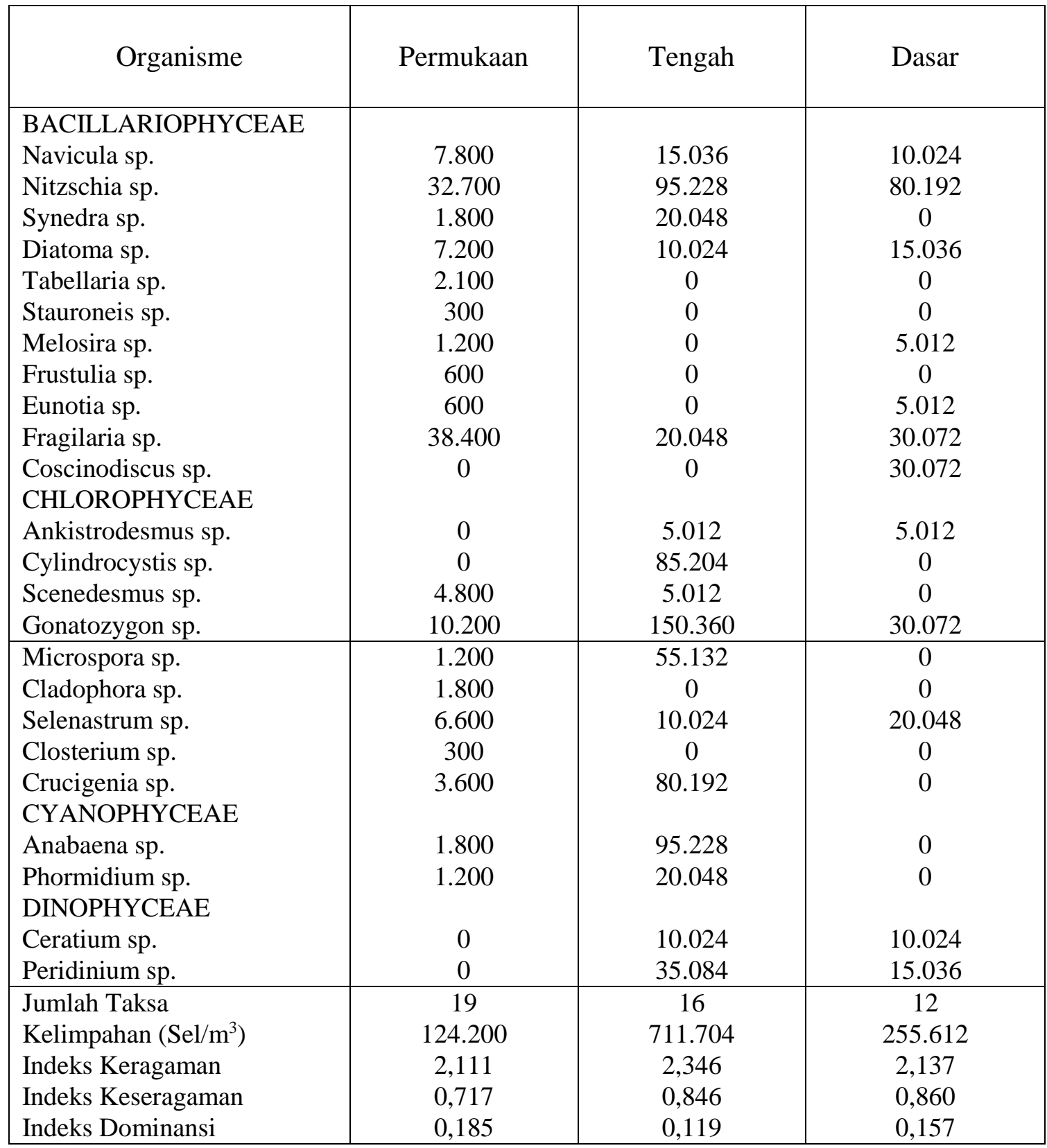

masing genera perkelas secara berturut-

Genera fitoplankton yang ditemukan di stasiun 3 Waduk Cirata selama penelitian sebanyak 24 genera yang mewakili 4 kelas, yaitu Bacillariophyceae Chlorophyceae, Cyanophyceae, dan Dinophyceae yang tersebar di seluruh kedalaman Genera fitoplankton dari kelas Bacillariophyceae merupakan genera yang paling banyak ditemukan Jumlah masing- turut adalah 11 genera Bacillariophyceae, 9 genera Chlorophyceae, 2 genera Cyanophyceae, dan 2 genera Dinophyceae. Kelimpahan fitoplankton berkisar 124.200 - $711.704 \mathrm{Sel} / \mathrm{m}^{3}$.

Dari Tabel 3 dapat dilihat bahwa indeks keanekaragaman fitoplankton berkisar antara 2,111 - 2,346. Hal ini menunjukkan bahwa stasiun 3 memiliki 
Tabel 4. Kelimpahan Zooplankton ( $\left.\mathrm{Ind} / \mathrm{m}^{3}\right)$ stasiun 1

\begin{tabular}{|c|c|c|c|}
\hline Organisme & Permukaan & Tengah & Dasar \\
\hline ROTIFERA & & & \\
\hline Brachionus sp. & 24.300 & 140.336 & 110.264 \\
\hline Keratella sp. & 4.800 & 80.192 & 90.216 \\
\hline Trichocerca sp. & 5.100 & 15.036 & 10.024 \\
\hline Rotaria sp. & 300 & 10.024 & 5.012 \\
\hline Notholca sp. & 2.100 & 15.036 & 5.012 \\
\hline Polyarthra sp. & 300 & 0 & 0 \\
\hline Mytilina sp. & 0 & 0 & 10.024 \\
\hline Synchaeta sp. & 300 & 0 & 0 \\
\hline MALACOSTRACA & & & \\
\hline Cyclops sp. & 0 & 0 & 10.024 \\
\hline Calanus sp. & 600 & 5.012 & 0 \\
\hline Bosmina sp. & 0 & 10.024 & 0 \\
\hline Nauplius & 11.100 & 10.024 & 185.444 \\
\hline Jumlah Taksa & 9 & 8 & 8 \\
\hline Kelimpahan (Ind/m³) & 48.900 & 285.684 & 426.020 \\
\hline Indeks Keragaman & 1,431 & 1,439 & 1,410 \\
\hline Indeks Keseragaman & 0,651 & 0,692 & 0,678 \\
\hline Indeks Dominansi & 0,321 & 0,330 & 0,303 \\
\hline
\end{tabular}

tingkat keanekaragaman rendah. indeks keseragaman berkisar $0,717-0,860$ hal ini menunjukkan keseragaman tinggi, artinya penyebaran individu tersebut mendekati merata atau tidak ada spesies yang mendominasi. Nilai indeks dominansi berkisar 0,119 - 0,185 . Artinya tidak terdapat genus yang secara ekstrim mendominasi genus lainnya.

2. Jenis - jenis zooplankton yang ditemukan pada waduk Cirata Genera zooplankton yang ditemukan di stasiun 1 Waduk Cirata selama penelitian sebanyak 12 genera yang mewakili 2 kelas, yaitu Rotifera, dan Malacostraca yang tersebar di seluruh kedalaman. Jumlah masing-masing genera perkelas secara berturut-turut adalah 8 genera Rotifera dan 4 genera Malacostraca. Kelimpahan zooplankton berkisar 48.900 426.020 Sel $/ \mathrm{m}^{3}$.

Dari Tabel 4 dapat dilihat bahwa indeks keanekaragaman zooplankton berkisar antara $1,410-1,439$. Hal ini menunjukkan bahwa stasiun1 memiliki tingkat keanekaragaman rendah. indeks 
keseragaman berkisar 0,651 - 0,692 hal ini menunjukkan keseragaman tinggi, artinya penyebaran individu tersebut mendekati merata atau tidak ada spesies yang mendominasi. Nilai indeks dominansi berkisar $0,303-0,330$. Artinya tidak terdapat genus yang secara ekstrim mendominasi genus lainnya.

Tabel 5. Kelimpahan Zooplankton ( $\mathrm{Ind} / \mathrm{m}^{3}$ ) stasiun 2

\begin{tabular}{|l|l|l|l|}
\hline \multicolumn{1}{|c|}{ Organisme } & \multicolumn{1}{c|}{ Permukaan } & Tengah & \multicolumn{1}{c|}{ Dasar } \\
& & & \\
ROTIFERA & & & \\
Brachionus sp. & 1.500 & 15.036 & 5.012 \\
Keratella sp. & 5.100 & 90.216 & 5.012 \\
Trichocerca sp. & 2.100 & 75.180 & 15.036 \\
Euchlanis sp. & 300 & 0 & 5.012 \\
Testudinella sp. & 300 & 5.012 & 5.012 \\
CILIATA & & & \\
Stylonychia sp. & 1.200 & 10.024 & 0 \\
MALACOSTRACA & & & \\
Cyclops sp. & 2.700 & 10.024 & 20.048 \\
Diaptomus sp. & 600 & 0 & 0 \\
Calanus sp. & 0 & 5.012 & 0 \\
Daphnia sp. & 0 & 5.012 & 0 \\
Bosmina sp. & 600 & 0 & 10.024 \\
Nauplius & 5.100 & 50.120 & 20.048 \\
\hline Jumlah Taksa & 10 & 9 & 8 \\
Kelimpahan (Ind/m $\left.{ }^{3}\right)$ & 19.500 & 265.636 & 85.204 \\
Indeks Keragaman & 1,927 & 1,673 & 1,905 \\
Indeks Keseragaman & 0,837 & 0,762 & 0,916 \\
Indeks Dominansi & 0,180 & 0,238 & 0,170 \\
\hline & & & \\
\hline
\end{tabular}

Genera zooplankton yang ditemukan di stasiun 2 Waduk Cirata selama penelitian sebanyak 12 genera yang mewakili 3 kelas, yaitu Rotifera, Ciliata dan Malacostraca yang tersebar di seluruh kedalaman Jumlah masing-masing genera perkelas secara berturut-turut adalah 5 genera Rotifera ,1 genera Ciliata, dan 6 genera Malacostraca. Kelimpahan zooplankton berkisar 19.500 - 265.636 $\mathrm{Sel} / \mathrm{m}^{3}$.
Dari Tabel 5 dapat dilihat bahwa indeks keanekaragaman zooplankton berkisar antara 1,673 - 1,927. Hal ini menunjukkan bahwa stasiun2 memiliki tingkat keanekaragaman rendah. indeks keseragaman berkisar 0,762 - 0,916 hal ini menunjukkan keseragaman tinggi, artinya penyebaran individu tersebut mendekati merata atau tidak ada spesies yang mendominasi. Nilai indeks dominansi berkisar 0,170-0,238. Hal ini disebutkan 
oleh Basmi (2000) bahwa kisaran nilai indeks dominansi mulai dari 0-1, apabila nilai yang didapatkan mendekati nol berarti di dalam struktur komunitas biota yang diamati tidak terdapat genus yang secara ekstrim mendominasi genus lainnya. Genera zooplankton yang ditemukan di stasiun 3 Waduk Cirata selama penelitian sebanyak 13 genera yang mewakili 3 kelas, yaitu Rotifera, Rhizopoda dan Malacostraca yang tersebar di seluruh kedalaman Jumlah masingmasing genera perkelas secara berturutturut adalah 8 genera Rotifera , 1 genera Rhizopoda, dan 4 genera Malacostraca. Kelimpahan zooplankton berkisar 45.600 $260.624 \mathrm{Sel} / \mathrm{m}^{3}$.
Dari Tabel 6 dapat dilihat bahwa indeks keanekaragaman zooplankton berkisar antara 1,428 - 1,769. Hal ini menunjukkan bahwa stasiun 3 memiliki tingkat keanekaragaman rendah. Indeks keseragaman berkisar $0,768-0,887$ hal ini menunjukkan keseragaman tinggi, artinya penyebaran individu tersebut mendekati merata atau tidak ada spesies yang mendominasi. Nilai indeks dominansi berkisar 0,214 - 0,260 . Artinya tidak terdapat genus yang secara ekstrim mendominasi genus lainnya.

Landner (1978) status trofik berdasarkan kelimpahan fitoplankton yaitu:

Tabel 6. Kelimpahan Zooplankton $\left(\mathrm{Ind} / \mathrm{m}^{3}\right)$ stasiun 3

\begin{tabular}{|l|l|l|l|}
\hline & Permukaan & Tengah & Dasar \\
\hline Organisme & & & \\
\hline Brachionus sp. & 13.800 & 20.048 & 35.084 \\
Keratella sp. & 8.700 & 105.252 & 5.012 \\
Mytilina sp. & 1.800 & 0 & 0 \\
Notholca sp. & 4.200 & 10.024 & 0 \\
Trichocerca sp. & 900 & 45.108 & 40.096 \\
Rotaria sp. & 0 & 5.012 & 0 \\
Polyarthra sp. & 0 & 10.024 & 0 \\
Testudinella sp. & 0 & 5.012 & 0 \\
RHIZOPODA & & & \\
Difflugia sp. & 600 & 0 & 0 \\
MALACOSTRACA & & & \\
Cyclops sp. & 600 & 5.012 & 0 \\
Diaptomus sp. & 600 & 0 & 0 \\
Bosmina sp. & 2.100 & 10.024 & 15.036 \\
Nauplius & 12.300 & 45.108 & 45.108 \\
\hline Jumlah Taksa & 10 & 10 & 5 \\
Kelimpahan (Ind/m & & \\
Indeks Keragaman & 45.600 & 260.624 & 140.336 \\
Indeks Keseragaman & 1,769 & 1,775 & 1,428 \\
Indeks Dominansi & 0,768 & 0,771 & 0,887 \\
\hline
\end{tabular}


Perairan Oligotrofik merupakan perairan yang tingkat kesuburan rendah dengan kelimpahan fitoplankton berkisar antara 0 $-2000 \mathrm{ind} / \mathrm{ml}$.

-Perairan Mesotrofik merupakan perairan yang tingkat kesuburan sedang dengan kelimpahan fitoplankton berkisar antara $2000-15.000 \mathrm{ind} / \mathrm{ml}$.

- Perairan Eutrofik merupakan perairan yang tingkat kesuburan sedang dengan kelimpahan fitoplankton berkisar antara $>15.000 \mathrm{ind} / \mathrm{ml}$

Goldman and Horne, 1994 menggolongkan, yaitu:

- Oligotrofik yaitu perairan tersebut mempunyai tingkat kesuburan rendah dengan kelimpahan zooplankton kurang dari 1 ind/lt,

- Mesotrofik yaitu perairan yang mempunyai tingkat kesuburan sedang dengan kelimpahan zooplankton antara $1-500 \mathrm{ind} / \mathrm{lt}$,

- Eutrofik yaitu perairan yang mempunyai tingkat kesuburan tinggi dengan kelimpahan zooplankton lebih dari 500 ind/lt.

Berdasarkan indeks keanekaragaman plankton menunjukkan bahwa keseluruhan stasiun memiliki tingkat keanekaragaman rendah.

\section{SIMPULAN}

- Genera fitoplankton yang ditemukan di Waduk Cirata sebanyak 19-26 genera yang mewakili 4-5 kelas, yaitu Chlorophyceae, Cyanophyceae, Bacillariophyceae, Dinophyceae dan Euglenaphyceae

- Genera zooplankton yang ditemukan di Waduk Cirata sebanyak 12-13 genera yang mewakili kelas, yaitu Rotifera, Rhizopoda, Ciliata dan Malacostraca

- Kelimpahan fitoplankton berkisar $91.200-1,328.180 \quad \mathrm{Sel} / \mathrm{m}^{3}$ dan kelimpahan Zooplankton berkisar 19.500 - $426.020 \mathrm{Sel} / \mathrm{m}^{3}$,

\section{DAFTAR PUSTAKA}

Basmi, J. 2000. Planktonologi : Plankton Sebagai Bioindikator kualitas Perairan. Fakultas Perikanan dan Ilmu Kelautan. IPB. Hal : 40.

Brower JE, Zar JH. 1990. Field and Laboratory Methods for General Ecology. 3rd Edition. Dubuque, Lowa: C. Brown Publisher

Effendi H. 2003. Telaah Kualitas Air Bagi Pengelolaan Sumberdaya dan Lingkungan Perairan. Yogyakarta. Kanisius.

Goldman CR., and Horne AJ., 1994, Limnology, Mc. Graw Hill Book Co. USA Landner, 1978. Eutrophication of lakes. Analysis Water and Air Pollution Research Laboratory Stockholm. Sweden 
Nybakken, J.W. 1992. Biologi Laut Suatu Pendekatan Ekologis. PT. Gramedia Pustaka Utama, Jakarta: xv +240 hal.

Poernomo MA, Hanafi. 1982. Analisa kualitas air untuk keperluan perikanan. Di dalam: Training Penyakit Ikan. Bogor: Balai
Penelitian Perikanan Darat. Staf Laboratorium Kimia. 49 hal.

Subarijanti, H.U. 1990. Diktat Kuliah Limnology. NUFFIC/ UNIBRAW/ LUW/ FISH. Universitas Brawijaya. Malang

Wetzel, R. G. 1975. Limnology. Michigan State University. Sainders Co. Chicago 